(В. Поляков). В. Ісаєв присвятив своє дослідження корпоративному навчанню менеджерів готельного бізнесу за допомогою ділової гри.

Варто виокремити роботу Х. Найдьонова, присвячену змісту, формам і методам додаткового професійного навчання менеджерів готелів. В Україні відсутня практика організації додаткової освіти, тому дослідження в цьому напрямі не проводяться.

Партнерство навчальних закладів та готельних підприємств наразі $€$ важливим для якісної підготовки майбутніх фахівців, але нині, незважаючи на актуальність, ця проблема є практично не розробленою на теоретичному рівні. Виняток складає лише робота Ю. Галаніна, у якій розкриваються технологія та структура взаємодії вишів та готельних комплексів у професійній підготовці кадрів.

Виявлені та проаналізовані нами роботи з теорії та практики підготовки фахівців для готельного господарства дозволяють зробити такі висновки: кількість цих досліджень незначна; присвячені вони переважно різним аспектам підготовки фахівців у вищих навчальних закладах та мають прикладний характер; науковці недостатньо чітко окреслюють зміст основних понять та дефініцій.

3-поміж основних напрямів досліджень виокремлюємо: формування професійної компетентності, дидактичні аспекти професійної підготовки кадрів, навчальнометодичне забезпечення процесу навчання, забезпечення принципів неперервності та наступності, розроблення основ навчального процесу в різних типах навчальних закладів професійної освіти в готельному господарстві. Значна кількість робіт орієнтована на вищу освіту.

Недостатньо розробленими до цього часу залишаються проблеми навчальнометодичного забезпечення, організації практик, забезпечення принципів неперервності та наступності у процесі підготовки, управління якістю навчально-виховного процесу тощо.

Науковці роблять тільки перші кроки в напрямку розв'язання нагальних проблем, але перш за все, на нашу думку, потрібно визначитися з основними поняттямисистеми професійної освіти в галузі готельного господарства, розробити модель підготовки фахівця з готельного обслуговування та спрогнозувати розвиток професійної освіти, визначивши потреби готельного бізнесу, що й буде становити перспективні напрямки подальших наших досліджень.

\title{
Література
}

1. Віндюк А. В. Теоретичні і методичні засади професійної підготовки майбутніх фахівців з готельно-курортної справи в умовах ступеневої освіти : автореф. дисна здобуття наук. ступеня д-ра пед. наук/ А. В. Віндюк. - Запоріжжя, 2012. - 40 с. 2. Каталог авторефератов и диссертаций по педагогике, научные работы и статьи [Електронний ресурс]// Библиотека авторефератов и диссертаций по педагогике в Российской Федерации. - Режим доступу :http://naukapedagogika.com/t/teoriya-i-metodika-professionalnogo-obrazovaniya / (Дата звернення 23. 03. 2014 р.) 3. Полуда В. В. Оцінювання професійної компетентності майбутнього фахівця готельної справи/ В. В. Полуда // Збірник наукових праць. - Вінниця 2009. - Випуск 22. - С. 165-170. 4. Протоколи засідань Міжвідомчої ради 3 координації наукових досліджень 3 педагогічних та психологічних наук в Україні [Електронний ресурс] // Національна академія педагогічних наук України. Режим доступу : http://naps.gov.ua/ua/iccr/protocols/ (Дата звернення 23.02.2014 p.)

УДК: $37+1-73-008$

Вікторія Корнещук

\section{КОРПОРАТИВНА КУЛЬТУРА В ЗАКЛАДАХ ОСВІТИ}

Корнещук В. В. Корпоративна культура в закладах освіти.

У роботі окреслено загальні теоретичні засади корпоративної культури, доведено 
необхідність ії вивчення та розвитку для забезпечення ефективної діяльності установ, зокрема освітніх. Подано результати кількісного та якісного аналізу результатів діагностування корпоративної культури, проведеного на базі ОНПУ.

Ключові слова:корпоративна культура, організація, заклад освіти, педагогічний колектив, персонал.

Корнещук В. В. Корпоративная культура в образовательных учреждениях.

В работе обозначены общие теоретические основы корпоративной культуры, показана необходимость её изучения и развития для обеспечения эффективной деятельности учрежнений, в том числе учебных. Представлены результаты количественного и качественного анализа результатов диагностирования корпоративной культуры, проведеного на базе ОНПУ.

Ключевые слова:корпоративная культура, организация, образовательное учреждение, педагогический коллектив, персонал.

Korneshcuk V. V. Corporate culture in the educational institutions.

The article is defined common theoretical foundations of corporate culture and also shown the necessity of her studying and development for ensuring effective activity of institutions including academic. The results of quantitative and qualitative analysis of corporate culture diagnosis conducted on the base of Odessa National Polytechnic University are presented.

Key words:corporate culture, organization, educational institution, pedagogical staff, staff.

Корпоративна культура є нині одним із провідних чинників розвитку організації шляхом розвитку іiі людського капіталу, оскільки пов'язує організаційні процеси, їх виконавців і керівництво. Саме особливості корпоративної культури організації впливають на ступінь їі стабільності, конкурентоспроможність, управлінські рішення, здатність досягати запланованих результатів.

Вивченню корпоративної культури в організаціях різних форм власності присвячено чимало робіт закордонних та вітчизняних (М. Армстронг, С. Василенко, О. Віханський, Н. Гончарова, Л. Елдрідж, П. Журавльов, С. Девіс, К. Камерон, А. Карпов, В. Козлов, А. Кромбі, Р. Кричевський, Р. Куїн, С. Малютін, Г. Морган, А. Наумов, У. Оучі, Ю. Палеха, Т. Питерс, В. Сате, Ю. Семенов, Т. Соломанідіна, В. Співак, В. Томілов, Р. Уотерман, Е. Шейн, Х. Шварц, К. Шольтс, Г. Хофстеде та ін.) дослідників. Проте переважна більшість наукових розробок присвячена корпоративній (організаційній) культурі комерційних організацій, тоді як корпоративну культуру закладів освіти, що мають працювати в нових економічних умовах, надавати якісні (зокрема оплатні) освітні послуги, - досліджено недостатньо.

Mema cmammi - проаналізувати стан корпоративної культури вищого навчального закладу (на прикладі Одеського національного політехнічного університету).

Нині мають місце чимало поглядів щодо розуміння сутності корпоративної культури, яку визначають як комплекс базових припущень, винайдений, виявлений або розроблений групою для того, щоб навчитися справлятися 3 проблемами зовнішньої адаптації і внутрішньої інтеграції (Е. Шейн); неявну, невидиму й неформальну свідомість організації, яка управляє поведінкою людей i, в свою чергу, сама формується під упливом їх поведінки (К. Шольтс); сукупність переконань, ставлень, норм поведінки і цінностей, спільних для всіх співробітників певної організації (М. Армстронг); вираження основних цінностей в організаційній структурі, системі управління, кадровій політиці (В. Томілов).

Вищевисловлене дозволяє дійти висновку, що корпоративна культура - це 
сукупність цінностей, переконань, стосунків, спільних для всіх співробітників цієї організації, що зумовлюють норми їхньої поведінки. Вони можуть не бути чітко виражені, але за відсутності прямих інструкцій визначають спосіб дії і взаємодії людей i значною мірою впливають на хід виконання роботи i на характер життєдіяльності організації. Отже, корпоративна культура формує спільний (культурний) простір, що включає цінності, норми і поведінкові моделі, що поділяють усі працівники, й узгоджує тим самим індивідуальні цілі працівників із загальною метою організації.

Таке розуміння корпоративної культури дозволяє визначити іï структуру, а саме:

- переконання - уявлення працівника про те, що є правильним в організації;

- цінності, що домінують в організації;

- норми - непрописані правила поведінки, що підказують працівникам, як вони мають поводитися, чого від них очікують (слід зауважити, що норми поведінки відбивають такі моменти в діяльності організації, як: стосунки керівник - підлеглий; чесність і дотримання законодавства; поведінка при конфліктах інтересів; отримання і використання інформації про інші організації; політична діяльність всередині організації; використання ресурсів організації тощо);

- поведінка - щоденні дії, які працівники здійснюють у процесі роботи і у зв'язку зі своєю роботою при взаємодії з іншими (ритуали і церемонії, мова спілкування);

- психологічний клімат - усталена система внутрішніх зв'язків колективу, що проявляється в емоційному настрої, громадській думці і результатах діяльності (саме психологічний клімат в організації свідчить про те, як працівники сприймають наявну в ній культуру, що думають і відчувають зії приводу).

Намагання науковців вивчити корпоративну культуру організації невипадкові, оскільки iї значення для працівників зумовлено низкою функцій, що вона виконує. По-перше, вона надає співробітникам організаційну ідентичність, визначає колективне уявлення про організацію, аджеє джерелом стабільності і наступності в ній. Так, корпоративна культура створює у працівників відчуття надійності самої організації і свого становища в ній, сприяє формуванню почуття соціальної захищеності. По-друге, знання основ корпоративної культури допомагає новим працівникам правильно інтерпретувати події, що відбуваються в організації. По-третє, корпоративна культура стимулює відповідальність працівника, який виконує поставлені перед ним завдання: визнаючи і нагороджуючи таких людей, корпоративна культура «робить» їх зразками для наслідування.

Дослідження показують, що корпоративна культура може сприяти підвищенню ефективності діяльності організації, впровадженню інновацій, але й «працювати» проти організації, створюючи бар'єри, що перешкоджають виробленню i реалізації корпоративної стратегії. Ці бар'єри спричиняють опір новому й неефективні комунікації.

Уплив корпоративної культури на ефективність організації визначається передусім її відповідністю загальній стратегії цієї організації. Можна виокремити такі основні підходи до розв'язання проблеми несумісності стратегії і культури в організації:

- організаційна культура ігнорується членами колективу, що перешкоджає ефективному впровадженню обраної організацією стратегії;

- система управління підпорядковується наявній в організації культурі;

- корпоративна культура змінюється відповідно до обраної стратегії;

- стратегія змінюєтьсяна відповідну корпоративній культурі.

Дослідження корпоративної культури організації дозволяє розв’язати триєдину 
задачу: 1) виявити провідні цінності, пріоритети, настанови, покликані підтримати перспективну організаційну стратегію; 2) з'ясувати, які цінності допомагатимуть (чи заважатимуть) реалізації стратегічних цілей організації; 3) оцінити міру відповідності реальної корпоративної культури стратегії розвитку організації, виробленої керівництвом.

Знання стану корпоративної культури в освітніх установах дозволяє розробити цілеспрямовану програму та рекомендації керівництву щодо іiі подальшого розвитку. Загалом, такими рекомендаціями є:

1. Підтримка ефективних міжособистісних взаємовідносин усередині педагогічного колективу, налагодження зворотного зв'язку, що забезпечується поважним ставленням і розв'язанням міжособистісних та особистих проблем працівників.

2. Попередження та виявлення міжособистісних конфліктів, конфліктів між окремими групами; аналіз причини їх виникнення та впровадження необхідних заходів для їх вирішення.

3. Виявлення потреб 3 підвищення кваліфікації педагогічних працівників у кожному підрозділі, визначення їхніх пріоритетних потреб і розроблення програм професійного зростання. Створення гнучкої системи професійного навчання, зорієнтованого на розв'язання стратегічних завдань освітньої установи.

4. Надання нижчим рівням управління більше прав щодо ухвалення рішень; проведення моніторингу ідей працівників щодо нововведень в освітньому закладі.

5. Створенняатмосфери взаємної співпраці, довіри; підвищення рівня турботи про педагогічний персонал 3 боку керівництва та на всіх рівнях управління; сприянняусвідомленню працівниками цілей навчального закладу.

6. Підвищення рівня довіри в освітній установі шляхом створення умов для задоволення потреб педагогічного персоналу щодо:

1) справедливої заробітної платні (однакова платня за однакову роботу, справедливо обгрунтована диференціація додаткових виплат);

2) умови безпеки праці та охорони здоров'я;

3) гарантії зайнятості (забезпечення безперервності трудового стажу педагогічного працівника і впевненості у своєму майбутньому);

4) соціальної інтеграції (налагодження стосунків керівників і підлеглих, що сприяють відвертості та довірі);

5) участі педагогічних працівників в управлінні навчальним закладом, заохочення ініціативи, висування нових ідей;

6) демократії в освітній установі (свобода слова, право на невтручання в особисте життя, відсутність будь-якої дискримінації і право на участь у всіх пов’язаних з роботою заходах);

7) упровадження мотиваційних заходів, як-от: посилення матеріального стимулювання за конкретні професійні здобутки; забезпечення педагогічного та допоміжного персоналу навчального закладу необхідними матеріальними засобами, офісною технікою, приміщенням відповідно до науково обгрунтованих норм;забезпечити можливість для самореалізації в роботі, підвищення педагогічної майстерності, досягнення певних успіхів у роботі.

На нашу думку, вивчення стану та розвиток корпоративної культури дозволяє сформувати в навчальному закладі таку ціннісно-нормативну систему, яка забезпечує особли вий психологічний стан у педагогічному колективі,зумовлює відчуття відповідальності працівників, їхню зацікавленість, успіх, значущість; яка сприяє підвищенню якості професійної діяльності педагогічного персоналу, задоволеності від роботи; зміцнює стабільність та ефективність діяльності освітньої установи в цілому. 
Слід зауважити, що розроблено низку способів вивчення корпоративної культури: інтерв'ю й анкетування; вивчення усного фольклору, документів, правил, традицій, церемоній і ритуалів, що склалися в організації; аналіз наявної практики управління; непрямі методи тощо.

Щоб виявити стан корпоративної культури вищого навчального закладу на базі Одеського національного політехнічного університету, було проведене пілотне дослідження. У діагностуванні взяли участь 44 викладачі та 6 осіб навчальнодопоміжного персоналу. До вибірки було включено респондентів, які мають багаторічний стаж роботи в університеті, а також стаж роботи до 1 року. 12\% вибірки - респонденти чоловічої статі.

Згідно 3 методикою діагностування «Оцінка рівня організаційної культури» I. Ладанова [1] респонденти оцінювали за 10-бальною шкалою запропоновані їм твердження - показники корпоративної культури. Надалі підраховували загальну суму балів та визначалирівень корпоративної культури (261-290 - досить високий; 175-260 - високий; 115-175 - середній; нижче за 115 - свідчить про тенденцію до деградації). Загальна сума, що перевищує 175 балів, свідчить про позитивну спрямованість організаційної культури. Крім того, методика дозволяла виявити та проаналізувати цінності корпоративної культури за такими критеріями, як-от: робота, управління, мотивація і мораль, комунікація (середній бал у 9-10 за кожним показником свідчив про чудовий стан; 6-8 балів - мажорний; 4-5 - помітний смуток; 1-3 - занепад). Результати пілотного дослідження корпоративної культури узагальнено в таблиці.

Таблиия

Рівні корпоративної культури

\begin{tabular}{|l|l|l|l|l|l|l|}
\hline \multicolumn{2}{|c|}{$\begin{array}{l}\text { Загальний рівень } \\
\text { корпоративної культури }\end{array}$} & \multicolumn{5}{|c|}{ Стан колективу за показниками: } \\
\cline { 4 - 8 } & & & Робота & Комунікація & Управління & \multicolumn{1}{c|}{$\begin{array}{c}\text { Мотивація і } \\
\text { мораль }\end{array}$} \\
\hline Досить високий & $28 \%$ & Гармонійний & $36 \%$ & $24 \%$ & $28 \%$ & $16 \%$ \\
\hline Високий & $64 \%$ & Мажорний & $52 \%$ & $72 \%$ & $64 \%$ & $76 \%$ \\
\hline Середній & $8 \%$ & $\begin{array}{l}\text { Помітний } \\
\text { смуток }\end{array}$ & $12 \%$ & $4 \%$ & $8 \%$ & $4 \%$ \\
\hline $\begin{array}{l}\text { Схильний } \\
\text { деградації }\end{array}$ & $0 \%$ & Занепад & $0 \%$ & $0 \%$ & $0 \%$ & $4 \%$ \\
\hline
\end{tabular}

Як можна бачити 3 таблиці, 28\% респондентів уважають, що загальний рівень корпоративної культури в їхньому педагогічному колективі $є$ досить високим, 64\% респондентів - високим, 8\% - середнім. Жоден із респондентів не висловив думки щодо схильності корпоративної культури до деградації. Більш якісні відомості про загальний стан корпоративної культури в досліджуваному колективі надає його середнє значення, що становить 229,36. Отже, загальний рівень корпоративної культури слід уважати високим. Організаційна культура в університеті має позитивну спрямованість.

Проаналізуємо стан корпоративної культури за іiі окремими критеріями. Щодо критерію «Робота», то $36 \%$ респондентів уважають його рівень гармонійним, 52\% мажорним. 12\% вказали на помітний смуток. Респондентів, які б засвідчили занепад за критерієм «Робота» виявлено не було. Середній бал за означеним критерієм становить 8,01 , що в цілому свідчить про мажорний рівень.

За критерієм «Комунікація» $24 \%$ респондентів вказали на іï чудовий рівень, $72 \%$ - на мажорний, 4\% вказали на помітний смуток. За цим критерієм занепаду виявлено не було. Середній бал за критерієм «Комунікація» становить 7,83, що також свідчить про мажорний рівень корпоративної культури в досліджуваному 
педагогічному колективі.

Щодо критерію «Управління», то 28\% респондентів вважають його чудовим, 64\% - мажорним. 8\% вказали на помітний смуток. Респондентів, які б засвідчили занепад за критерієм «Управління», також не виявлено. Середній бал за означеним критерієм становить 7,83, що відповідає мажорному рівню.

За критерієм «Мотивація і мораль» $16 \%$ респондентів вказали на чудовий рівень, $76 \%$ - на мажорний. По 4\% респондентів вказали на помітний смуток і занепад. Середній бал за критерієм «Мотивація і мораль» становить 7,92, що також свідчить про мажорний рівень корпоративної культури в досліджуваному педагогічному колективі.

Незважаючи на відповідність показників корпоративної культури за всіма критеріями мажорному рівню, можна констатувати, що найбільший середній бал відповідає показникам за критерієм «Робота» $(8,01)$. Трохи менший - за критеріями «Управління» $(7,92)$, «Комунікація» $(7,83)$ та «Мотивація і мораль» $(7,83)$.

Надамо якісну характеристику отриманим результатам. Так, аналіз результатів діагностування педагогічного персоналу ОНПУ за критерієм «Робота» свідчить про те, що нові співробітники мають можливість опанувати в університеті нову спеціальність,упідрозділах університету налагоджена доцільна система просування на нові посади. Працівники мають оптимальне трудове навантаження і все, що потрібно для роботи. Найбільшої середньої оцінки $(9,36)$ за зазначеним критерієм досяг показник «Робота нам подобається», а найменшого $(7,60)$ - «Робочі місця в нас облаштовані».

Щодо критерію «Комунікація», то респонденти зазначили, що в університеті діють чіткі інструкції і правила поведінки всіх категорій викладачів та навчальнодопоміжного персоналу; культивуються різноманітні форми та методи комунікації (ділові контакти, збори, інформаційні роздруківки тощо), заохочується двобічна комунікація; немає збоїв в отриманні інформації всередині університету. Найбільшої середньої оцінки $(8,28)$ за цим критерієм набув показник «У нашому університеті заохочується безпосереднє звернення завідувачів кафедр до керівництва», а найменшого $(7,32)$ - «У нашому університеті налагоджено систему комунікації».

Аналіз показників корпоративної культури за критерієм «Управління» засвідчив, що в університеті приймаються ефективні й своєчасні рішення,організована професійна оцінка діяльності викладачів, дисциплінарні заходи $\epsilon$ винятком, конфліктні ситуації розв'язуються з урахуванням наявних обставин, університет завжди налаштований на нововведення, педагогічний персонал бере участь у прийнятті рішень. Найбільшої середньої оцінки $(8,56)$ набув показник «Наша діяльність чітко й докладно організована», а найменшого $(6,96)-$ «У нас практикується делегування повноважень на нижчі ешелони управління».

Аналіз результатів діагностування педагогічних працівників університету за критерієм «Мотивація і мораль» свідчать про те, що в університеті заохочуються активність та ініціатива; колеги підтримують гармонійні взаємовідносини один 3 одним; в усіх підрозділах домінує корпорація та взаємоповага серед викладачів;взаємовідносини викладачів 3 керівництвом гідні високої оцінки. Найбільшої середньої оцінки за зазначеним критерієм $(8,60)$ набув показник «Наші викладачі відчувають гордість за свій університет», а найменшого $(5,72)$ - «Система заробітної платні не викликає в нас нарікань». Слід зазначити, що останній показник набув найменшого значення порівняно з усіма показниками за всіма критеріями. Цей недолік, на нашу думку, слід пов'язувати не стільки 3 керівництвом університету, скільки з економіко-політичними реаліями в країні загалом. 
Здійснений аналіз дозволяє дійти висновку щодо загальної задоволеності педагогічного персоналу рівнем корпоративної культури в університеті. Її найважливішими цінностями визнано доцільну організацію діяльності педагогічного та допоміжного персоналу, можливість професійного та кар'єрного зростання тощо. Подальший розвиток корпоративної культури в університеті зумовлений необхідністю облаштування комфортних робочих місць для педагогічного й допоміжного персоналу, оновлення навчально-матеріальної бази; налагодженні ефективної системи комунікації; забезпеченні можливості делегування повноважень на всіх рівнях управління; відновлення системи матеріального заохочення працівників тощо.

Розвиток корпоративної культури $є$ нині одним із пріоритетних напрямів розвитку будь-якої організації. Проте незважаючи на наявність грунтовної теоретичної бази щодо вивчення корпоративної культури комерційних організацій, відповідні здобутки для корпоративної культури в закладах освіти досить обмежені. На нашу думку, переносити теорію корпоративної культури організацій як таких на заклади освіти можна лише з урахуванням специфіки їх діяльності, специфіки послуг, що вони надають, i, нарешті, специфіки персоналу, що забезпечує надання освітніх послуг.

\section{Література}

1. Галкина Т. П. Социология управления: подготовка группы к команде:[учеб. пособ.] / Т. П. Галкина. - М. : Финансы и статистика, 2001. - С. 192-195. 2. Семенов Ю. Г. Организационная культура: управление и диагностика/ Ю. Г. Семенов. - Екатеринбург : Ин-т экономики УрОРАН, 2004. - 180 с. 3. Яценко А. М. Організаційно-культурні ресурси і механізми соціального управління:[монографія] / А. М. Яценко. - Одеса : Астропринт, 2003. - 205 с.

\section{ХУДОЖНЬО-ЕСТЕТИЧНИЙ СМАК ДІТЕЙ СТАРШОГО ДОШКІЛЬНОГО ВІКУ ТА ОСОБЛИВОСТІ ЙОГО ВИЯВУ}

Лазаренко Г. А. Художньо-естетичний смак дітей старшого дошкільного вікута особливості його вияву.

У дослідженні виявлені питання особливостей вияву художньо-естетичного смаку дітей старшого віку, а саме: емоційні реакції, їх потреби у сприйманні прекрасного, особливості сприйняття навколишніх i музичних звуків. Також 3'ясовано, що допомагають виявитися художньо-естетичному смаку музичнотеатральна діяльність, виконавська та творча активність дошкільників.

Ключові слова: художньо-естетичний смак, діти старшого дошкільного віку, емоції, сприйняття, музика.

Лазаренко Г. А. Художественно-эстетический вкус детей старшего дошкольного возраста и особенности его проявления.

В исследовании выявлены вопросы особенностей проявления художественноестетического вкуса детей старшего дошкольного возраста, а именно: эмоциональные реакции, потребность в восприятии прекрасного, особенности восприятия окружающих и музыкальных звуков. Так же выявлено, что помагают проявиться художесвенноэстетическому вкусу музыкально-театральная деятельность, исполнительская и творческая активность дошкольников.

Ключевые слова:художественно-эстетический вкус, дети старшего дошкольного возраста, эмоции, восприятие, музыка. 